|| ISSN(online): 2589-8698 || ISSN(print): 2589-868X || International Journal of Medical and Biomedical Studies

Available Online at www.ijmbs.info

PubMed (National Library of Medicine ID: 101738825)

Index Copernicus Value 2017: 40.03

\title{
EFFECT OF LYCOPENE IN AMELIORATION OF TESTICULAR AND RENAL TOXICITY INDUCED BY BOLDENONE UNDECYLENATE IN MALE ALBINO RATS
}

\author{
Samar S Ibrahim ${ }^{1}$, Alshaimaa M Said ${ }^{2 *}$ \\ ${ }^{1}$ Forensic Medicine and Toxicology Department, Faculty of Veterinary Medicine, Benha University, \\ Egypt. \\ ${ }^{2}$ Biochemistry Department, Faculty of Veterinary Medicine, Benha University, Egypt.
}

Article Info: Received 16 February 2019; Accepted 04 March. 2019

Cite this article as: Ibrahim, S., \& Said, A. (2019). EFFECT OF LYCOPENE IN AMELIORATION OF TESTICULAR AND RENAL TOXICITY INDUCED BY BOLDENONE UNDECYLENATE IN MALE ALBINO RATS. International Journal of Medical and Biomedical Studies, 3(3).

DOI: https://doi.org/10.32553/ijmbs.v3i3.124

Address for Correspondence: Alshaimaa M Said, Biochemistry Department, Faculty of Veterinary Medicine, Benha University. 13736 Moshtohor, Toukh, Qaliobiya, Egypt

Conflict of interest: No conflict of interest.

\section{Abstract}

Background: The present study was designed to evaluate the relative ameliorating efficacy of lycopene against the deleterious effects of boldenone, an androgenic steroid, on the rat testis and kidney. Materials and Methods: 40 male albino rats were divided into four groups; control group received intramuscular (i.m) injection of olive oil once a week; lycopene (Lc) group received lycopene (10 mg/kg b.w p.o daily); boldenone (Bol) group received ( $5 \mathrm{mg} / \mathrm{kg}$ b.w i.m once a week); Bol + Lc group received boldenone (5 mg/kg b.w i.m once a week) and lycopene (10 mg/kg b.w p.o daily) all for four weeks. Results: intramuscular injection of boldenone significantly induced lipid peroxidation and DNA fragmentation as well as inhibited total antioxidant capacity (TAC) and catalase (CAT) activity in testis and kidney tissue. Additionally, up-regulation of Bax and down-regulation of $\mathrm{Bcl}-2$ gene expression after Bol injection along with marked increase in serum inflammatory cytokines and decrease in serum testosterone. These alterations were confirmed by the histopathological examination of testis and kidney. On the other hand, lycopene oral administration attenuated the testicular and renal injuries induced by boldenone injection. Conclusion: administration of antioxidants as lycopene effectively ameliorated the adverse effects of boldenone on testis and kidney tissues.

Key words: Boldenone undecylenate, lycopene, DNA fragmentation, interleukin-1 $\beta$, tumor necrosis factor- $\alpha$, apoptosis.

\section{Introduction:}

The food gap, in the developing countries like Egypt, is increasing especially with animal proteins, which provide essential amino acids that cannot be synthesized inside the body but obtained through feeding on proteins of animal sources. Therefore, these countries are required to find effective methods to increase meat production (1). The anabolic steroids play an efficient role in improving growth rate and productivity of farm animals.

Boldenone (1,4-androstadiene-17b-ol-3-one) is an androgenic steroid used by athletes and bodybuilders to improve their physical performance and muscle size through promotion of positive nitrogen balance by stimulating 
protein anabolism and reducing protein catabolism beside water, nitrogen and electrolytes retention (2). Also, boldenone used as a growth promoter to improve the growth and food conversion in fattening animals (3).

According to the International Agency for Research on Cancer (IARC) the anabolic androgenic steroids are classified in class A2 (4). Moreover, these steroids caused some adverse effects on genital system, cardiovascular system and even central nervous system (5-7). The identification of boldenone main metabolite, which has a very long half-life, in meat, hair, urine or faeces plays a central role in the control of its unlawful use (8). Although boldenone is forbidden its illegal use triggers the need for investigating efficient protective agent that can counteract its deleterious effects.

The most abundant and effective singlet-oxygen quencher among carotenoids in tomatoes is lycopene (LC). It is one of the most potent antioxidants owing to its double bonds which make lycopene twice as powerful as $\beta$-carotene and 10 times as vitamin $E$ (9). Lycopene is the most prevalent carotenoid in human plasma found mainly in LDL and VLDL due to their lipophilic nature and in the adrenal gland, testes, liver and prostate gland $(10,11)$.

Lycopene suggested as a potential anticarcinogenic agent, particularly for prostate cancer (12). Moreover, it has been used after chemotherapy as an alternative treatment for sperm toxicity (13). Additionally, it has protective effects in chronic cardiovascular disorders as well as respiratory and gastrointestinal cancers (14).

\section{MATERIALS AND METHODS:}

\subsection{Chemical:}

Boldenone undecylenate supplied as patent preparation Boldex 450 component by Swiss labs (Ethyl oleate, benzyl alcohol and benzyl benzoate), each $1 \mathrm{~mL}$ per $10 \mathrm{~mL}$ vial contains 450 $\mathrm{mg}$ boldenone undecylenate for intramuscular use only sterile injection. Lycopene was obtained from DEBEIKY Pharmaceutical Company, Cairo, Egypt.

\subsection{Experimental animals:}

The forty male Wistar albino rats $(150 \pm 20 \mathrm{~g}$ weight) obtained from the animal house of Faculty of Veterinary Medicine, Benha University, Egypt. Animals were housed in separate cages under proper environmental conditions of temperature, humidity, light and fresh daily supplies of food and water. The animals were acclimatized to the laboratory conditions for 15 days before the experiment. The animal handling procedures in this study were approved by the Faculty of Veterinary Medicine Ethical Committee, Benha University, Egypt

\subsection{Experimental design:}

Rats were randomly allocated into four equal groups.

- Control group: rats received i.m injection of olive oil once a week.

- Lc group: rats administered lycopene dissolved in olive oil (10 mg/kg b.w p.o daily) (13).

- Bol group: rats received boldenone $(5 \mathrm{mg} / \mathrm{kg}$ b.w i.m injection once a week) (15).

- Bol + Lc group: rats received boldenone (5 $\mathrm{mg} / \mathrm{kg}$ b.w i.m injection once a week) and lycopene $(10 \mathrm{mg} / \mathrm{kg}$ b.w p.o daily) all for 28 successive days.

\subsection{Sampling:}

\subsubsection{Blood sample:}

After 24 hours of the last dose of lycopene the rats were anesthetized with diethyl ether then, blood samples were collected from the inner canthus of the eye by capillary tube into clean test tube for serum separation. The serum stored at $-20{ }^{\circ} \mathrm{C}$ until used for quantitative determination of interleukin-1 $\beta$ (IL-1 $\beta$ ), tumor necrosis factor- $\alpha$ (TNF- $\alpha$ ) and testosterone.

\subsubsection{Tissue specimens:}

Immediately after the collection of blood samples, the animals were euthanized. The testis 
and kidney specimens were quickly excised, rinsed in ice cold saline to exclude the blood cells and then blotted on filter paper. After that each organ (testis and kidney) were divided into three parts. The first part was kept at $-20{ }^{\circ} \mathrm{C}$ for determination of oxidative stress indices. The second part was kept at $-80{ }^{\circ} \mathrm{C}$ for gene expression and DNA fragmentation. The third part was placed in $10 \%$ formalin solution for histopathological investigation.

\subsection{Biochemical analysis:}

2.5.1. Serum IL-1 $\beta$, TNF- $\alpha$ and testosterone concentrations:

They were measured with commercially available ELISA kits following manufacturer protocol.

2.5.2. Evaluation of oxidative stress indices in testis and kidney tissue:

The tissues were cut, weighed $(1 \mathrm{~g})$ and suspended in $4 \mathrm{~mL}$ physiological saline for homogenization. The tissue homogenate were centrifuged $1500 \mathrm{rpm}$ for $20 \mathrm{~min}$ at $4{ }^{\circ} \mathrm{C}$ and the supernatant used for determination of biochemical parameters. MDA concentration (16), Total antioxidant capacity (TAC) (17), catalase (CAT) activity (18) and the percentage of DNA fragmentation (19) were estimated using special diagnostic kits obtained from (Biodiagnostics, Cairo, Egypt).

\subsection{Relative expression of Bax and $\mathrm{Bcl}-2$ genes in testis and kidney tissue:}

Total RNA was extracted from testis and kidney tissues using Gene JET RNA Purification Kit (Thermo Scientific, \# K0731, USA) following the manufacturer's protocol. RevertAid $\mathrm{H}$ Minus Reverse Transcriptase (Thermo Scientific, \#EP0451, USA) used to synthesize complementary DNA from $5 \mu \mathrm{g}$ of total RNA. The primer sequences used for amplification are GAPDH Forward: ATG GAG AAG GCT GGG GCT CAC CT. GAPDH Reverse: AGC CCT TCC ACG ATG CCA AAG TTG T. Bax Forward: CCA GGA CGC AT CAC CAA GAA GC. Bax Reverse: TGC CAC ACG GAA GAA GAG CTC TCG. BCl-2 Forward: GGA TGA CTT CTC TCG TCG CTA CCGT. BCl-2 Reverse: ATC
CCT GAA GAA GAC CTC TCG. Real time PCR with SYBER Green used to measure mRNAs expressions of $\mathrm{Bax}$ and $\mathrm{Bcl}-2$ genes with $\beta$ actin as housekeeping gene. The cycle threshold $(\mathrm{Ct})$ values were calculated for target genes and the GAPDH, and relative gene expression was determined using $2^{-\Delta \Delta C \mathrm{t}}$ method (20).

\subsection{Histopathological examination:}

Parts of the removed testis and kidney were fixed in $10 \%$ formalin for 24 hour. The tissue samples washed with tap water then dehydrated using serial dilutions of alcohol (methyl, ethyl and absolute ethyl). Specimens were embedded in paraffin blocks using the conventional embedding techniques. Then $4 \mu \mathrm{m}$ thick sections were cut, stained with (H\&E) and examined using light microscope.

\subsection{Statistical analysis:}

All obtained values were represented as means \pm standard error of means. Data analyzed using analysis of variance (ANOVA) followed by Duncan's multiple range test by statistical software package SPSS for Windows version 18.0 (SPSS, Chicago, IL, US) with $\mathrm{P}<0.05$ regarded as statistically significant.

\section{RESULTS:}

3.1. Effect of lycopene and/or boldenone on oxidative stress indices in testis and kidney:

As shown in table (1) Bol injected rats exhibited significantly higher MDA level and DNA fragmentation \% as well as decreased TAC and CAT activity in testis and kidney tissues. On the other hand, co-administration of Bol + LC showed decreased MDA concentration, DNA fragmentation $\%$ and increased TAC and CAT activity comparing to boldenone group. Administration of lycopene showed no effect on these parameters as compared to the control group.

\subsection{Effect of lycopene and/or boldenone on Bax} and $\mathrm{BCl}-2$ genes expression in testis and kidney:

Intramuscular injection of boldenone significantly up-regulated the Bax gene 
expression and down-regulated $\mathrm{Bcl}-2$ gene expression in testis and kidney tissues as compared to control group. These alterations were significantly ameliorated in rats coadministered lycopene with boldenone. No significant difference in $\mathrm{Bax}$ and $\mathrm{BCl}-2$ gene expression were noticed in rats administered LC compared to control group as shown in (table 2).

3.3. Effect of lycopene and/or boldenone on serum concentration of inflammatory cytokines and testosterone hormone:
Boldenone injection significantly increased IL-1 $\beta$ and TNF- $\alpha$ and decreased testosterone serum concentration. In contrary, co-administration of Bol + Lc showed decreased IL-1 $\beta$ and TNF- $\alpha$, increased testosterone concentration comparing to Bol group. Administration of lycopene showed no effect on inflammatory cytokines and testosterone hormone compared to the control group as presented in (table 3 ).

Table 1: Effect of lycopene and/or boldenone on MDA concentration, DNA Fragmentation \%, TAC and CAT activity in testis and kidney tissue:

\begin{tabular}{|c|c|c|c|c|c|}
\hline & & $\mathrm{MDA}(\mu \mathrm{mol} / \mathrm{g})$ & DNA F. $\%$ & TAC ( $\mu \mathrm{mol} / \mathrm{g})$ & CAT $(\mu \mathrm{mol} / \mathrm{g})$ \\
\hline \multirow{4}{*}{ 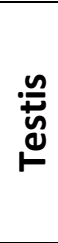 } & Control group & $37.11 \pm 2.55^{d}$ & $13.05 \pm 1.89^{c}$ & $58.83 \pm 2.10^{b}$ & $72.68 \pm 3.84^{\mathrm{a}}$ \\
\hline & Lc group & $32.15 \pm 2.12^{\mathrm{a}}$ & $13.04 \pm 1.39^{c}$ & $67.29 \pm 2.41^{\mathrm{a}}$ & $73.46 \pm 4.69^{\mathrm{a}}$ \\
\hline & Bol group & $80.93 \pm 3.57^{\mathrm{a}}$ & $35.79 \pm 2.77^{\mathrm{a}}$ & $24.44 \pm 1.59^{d}$ & $25.44 \pm 2.56^{\mathrm{c}}$ \\
\hline & Bol +Lc group & $54.82 \pm 2.59^{b}$ & $22.38 \pm 2.43^{b}$ & $45.38 \pm 2.36^{c}$ & $47.73 \pm 3.49^{b}$ \\
\hline \multirow{4}{*}{$\begin{array}{l}\text { बे } \\
\frac{c}{0} \\
\frac{0}{2}\end{array}$} & Control group & $25.98 \pm 1.85^{c}$ & $12.81 \pm 1.72^{c}$ & $38.95 \pm 1.78^{b}$ & $62.39 \pm 2.03^{\mathrm{a}}$ \\
\hline & Lc group & $22.57 \pm 1.66^{\mathrm{c}}$ & $13.05 \pm 1.65^{c}$ & $48.39 \pm 1.21^{\mathrm{a}}$ & $66.08 \pm 4.20^{\mathrm{a}}$ \\
\hline & Bol group & $53.68 \pm 1.81^{\mathrm{a}}$ & $36.13 \pm 3.28^{\mathrm{a}}$ & $13.75 \pm 0.81^{d}$ & $31.99 \pm 2.29^{c}$ \\
\hline & Bol +Lc group & $38.13 \pm 1.22^{b}$ & $21.79 \pm 2.36^{b}$ & $28.85 \pm 1.35^{c}$ & $47.79 \pm 3.00^{b}$ \\
\hline
\end{tabular}

Mean values with different superscript letters in the same column are significantly different at $(P \leq 0.05)$.

Table 2: Effect of lycopene and/or boldenone on Bax and Bcl-2 genes expression in testis and kidney tissue:

\begin{tabular}{|c|c|c|c|}
\hline & & Bax & $\mathrm{Bcl}-2$ \\
\hline \multirow{4}{*}{$\stackrel{n}{\stackrel{y}{y}}$} & Control group & $1.01 \pm 0.12^{c}$ & $1.00 \pm 0.01^{c}$ \\
\hline & Lc group & $1.02 \pm 0.03^{c}$ & $4.22 \pm 0.19^{a}$ \\
\hline & Bol group & $7.79 \pm 0.40^{a}$ & $0.91 \pm 0.02^{c}$ \\
\hline & Bol +Lc group & $5.72 \pm 0.24^{b}$ & $3.53 \pm 0.12^{b}$ \\
\hline \multirow{4}{*}{$\begin{array}{l}\text { d } \\
\frac{\partial}{0} \\
\frac{0}{2}\end{array}$} & Control group & $1.00 \pm 0.03^{c}$ & $1.02 \pm 0.04^{c}$ \\
\hline & Lc group & $1.08 \pm 0.04^{c}$ & $3.85 \pm 0.04^{a}$ \\
\hline & Bol group & $7.94 \pm 0.34^{a}$ & $0.94 \pm 0.02^{c}$ \\
\hline & Bol +Lc group & $5.17 \pm 0.25^{b}$ & $2.96 \pm 0.03^{b}$ \\
\hline
\end{tabular}

Mean values with different superscript letters in the same column are significantly different at $(P \leq 0.05)$. 
Table 3: Effect of Lycopene and/or boldenone on serum concentrations of IL-1 $\beta$, TNF- $\alpha$ and testosterone:

\begin{tabular}{|l|c|c|c|}
\hline \multicolumn{1}{|c|}{ Groups } & IL-1 $\boldsymbol{\beta}(\mathbf{n g} / \mathbf{m L})$ & TNF- $\boldsymbol{\alpha}(\mathbf{p g} / \mathbf{m L})$ & $\begin{array}{c}\text { Testosterone } \\
(\mathbf{n g} / \mathbf{m L})\end{array}$ \\
\hline Control group & $96.48 \pm 7.98^{\mathrm{c}}$ & $12.39 \pm 0.65^{\mathrm{c}}$ & $7.22 \pm 0.21^{\mathrm{a}}$ \\
\hline Lc group & $96.68 \pm 9.79^{\mathrm{C}}$ & $13.66 \pm 0.66^{\mathrm{c}}$ & $7.90 \pm 0.29^{\mathrm{a}}$ \\
\hline Bol group & $251.75 \pm 11.04^{\mathrm{a}}$ & $38.80 \pm 0.77^{\mathrm{a}}$ & $3.22 \pm 0.14^{\mathrm{c}}$ \\
\hline Bol +Lc group & $159.76 \pm 8.55^{\mathrm{b}}$ & $22.23 \pm 0.73^{\mathrm{b}}$ & $5.24 \pm 0.15^{\mathrm{b}}$ \\
\hline
\end{tabular}

Mean values with different superscript letters in the same column are significantly different at $(P \leq 0.05)$.

\subsection{Histopathological findings:}

Histopathological examination of the testis in control and LC groups showed normal histological structure of the mature active seminiferous tubules with complete spermatogenic series (Fig. 1A, B). Also, kidney of control and Lc rats showed normal histological structure of the glomeruli and tubules at the cortex (Fig. 2A, B). Whereas those injected with Bol exhibited degeneration with lose of spermatogenic series in some of the seminiferous tubules (Fig. 1C) and focal inflammatory cells infiltration in between the degenerated tubules at the cortex, associated with congestion in the tufts of the glomeruli and degeneration of the epithelial cells lining the tubules. Focal hemorrhages were detected in between renal tubules at the cortex, as well as in between the tubules at the corticomedullary junction (Fig. 2C). On the other hand, Co-administration of Bol + Lc preserve to a large extent the normal architecture of testis and kidney except mild thickening and edema in the interstitial stroma between the seminiferous tubules (Fig. 1D) and (Fig. 2D).

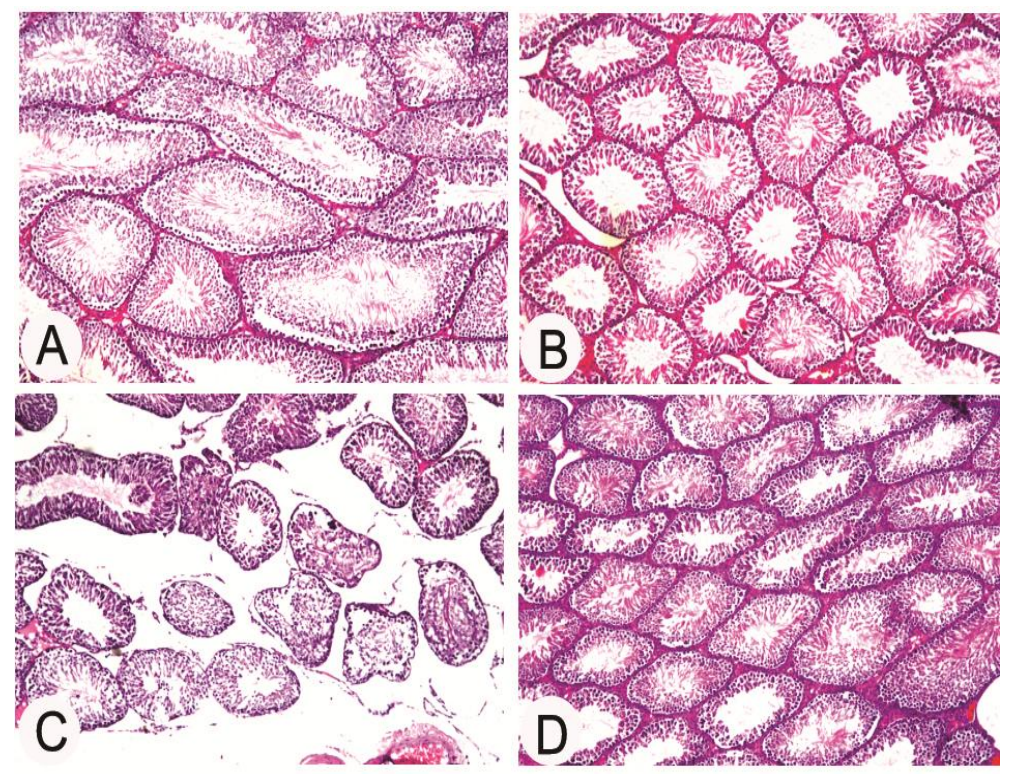

Figure 1: Testis; Rat: A) Control group: normal histological structure. B) Lc group: showing no histopathological alteration; C) Bol group: showing degeneration with loss of spermatogenic series. D) Bol +Lc group: showing mild histopathological alteration. 


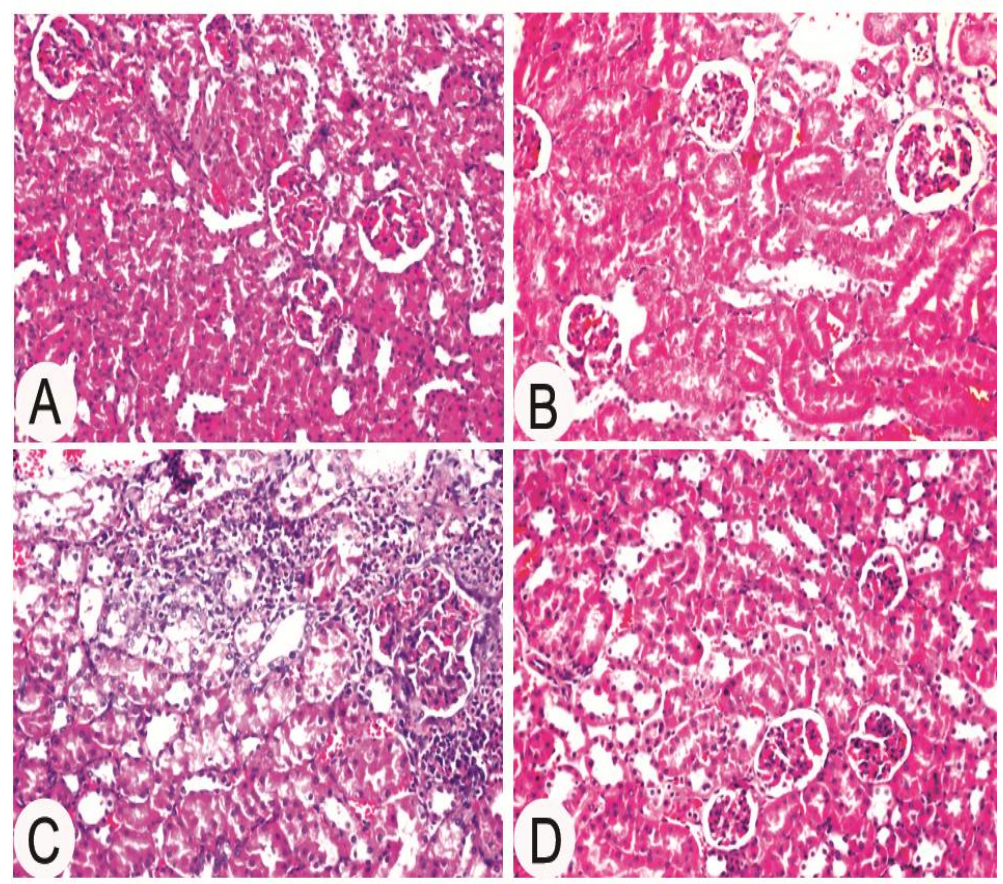

Figure 2: Kidney; Rat: A) Control group: normal histological structure. B) Lc group: showing no histopathological alteration; C) Bol group: showing focal inflammatory cells infiltration, congestion, degeneration and focal hemorrhages. D) Bol +Lc group: showing normal histological structure.

\section{DISCUSSION:}

The results of the present study revealed marked oxidative stress in testis and kidney tissues after Bol injection compared to normal control. This is consistent with the previous studies who reported that, the anabolic androgenic steroids induced oxidative stress as indicated by elevation of serum MDA level and alterations in the liver and kidney antioxidant defense systems $(21,22)$. The oxidative stress induced by boldenone injection could explain the increased DNA fragmentation as compared to control group.

Proapoptotic (Bax) and antiapoptotic ( $\mathrm{Bcl}-2)$ are involved in promoting either cell survival or cell death via apoptosis which occurs normally and continuously throughout life. Bax protein elevated levels accelerate cell death while elevated Bcl-2 level favors survival of cells (23). Enhanced rate of apoptosis as indicated by increased $\mathrm{Bax}$ and decreased $\mathrm{Bcl}-2$ expression after boldenone injection observed in this study may be related to the overproduction of reactive oxygen species and the resultant lipid peroxidation in testis and kidney tissues.

The cytokines interleukin-1 $\beta$ and TNF- $\alpha$ are key mediators of the inflammatory process. According to previous study IL-1 $\beta$ is involved in apoptosis and other cellular activities (24). Therefore, the increase in IL-1 $\beta$ concentration may be attributed to the elevated rate of apoptosis as indicated by increased Bax and decreased $\mathrm{Bcl}-2$ expression after boldenone injection. Moreover, it was reported that release of TNF- $\alpha$ induced by IL-1 $\beta$ which could explain the increase in TNF- $\alpha$ concentration (25).

Testosterone, male sex hormone secreted from testis, gives a good idea about the functional status of the testis (26). Our results showed a potent damaging effect of boldenone injection on testis as indicated by testosterone concentration and histopathological examination of testicular tissue. This is consistent with the decrease in testosterone, sperm count and motility observed in boldenone injected rabbits (2). Moreover, the previous study of Tousson et 
al. (1) recorded a decrease in testis weight and number of developing germ cells. The significant decrease in testosterone following the exogenous administration of boldenone may be attributed to inhibiting the gonadotropin releasing hormone secretion from hypothalamus and luteinizing hormone from pituitary gland (6).

On the other hand, administration of lycopene attenuated the oxidative stress induced by boldenone in testis and kidney tissues. These results came in agreement with those of Turk and co-authors (27) who observed that lycopene treatment significantly inhibited the lipid peroxidation, and improved the depletion in glutathione and antioxidant capacities of testicular tissue induced by cyclosporine A. Also, lycopene treatment had a potent effect on lowering the DNA fragmentation index $(28,29)$. The possible explanation for the protective effect of lycopene against oxidative stress induced by boldenone injection is its ability to react with the oxygen metabolites.

The ability of lycopene to react with oxygen metabolite could explain the remarkable attenuation of boldenone induced oxidative stress. During oxygen quenching, the lycopene molecule converted to the energy rich triplet state thus protecting against protein, lipid and DNA damage (30).

Moreover, co-treatment with lycopene to boldenone injected rats exhibited a decreased rate of apoptosis. Following the same trend Williams et al (31) reported an improvement in $\mathrm{Bax}$ and $\mathrm{BCl}-2$ positive staining provided by lycopene administrations to Aroclor treated rats. Moreover, there is a significant decrease in serum concentration of IL- $1 \beta$ and TNF- $\alpha$ observed after administration of lycopene to the boldenone injected rats comparing to Bol group. Such findings were enough to infer that lycopene can overcome the negative effects of boldenone injection by attenuating the oxidative stress.

In the current work there is a significant increase in serum testosterone concentration observed in rats co-administered $\mathrm{Bol}+\mathrm{LC}$ as compared to Bol group. These results came in accordance with those of Salem and Salem (32) who reported that, lycopene significantly improved the testosterone level in male rats. Also, lycopene prevent the adverse effects of cisplatin on sperm count, motility and abnormalities (33). Moreover, lycopene administration in men with idiopathic infertility exhibited an improvement in sperm characteristics (34).

Palan and Naz (1996) (35) reported that, lycopene concentration is low in seminal plasma of infertile men. Lycopene concentrated in the testes compared to other parts of the body which suggests that lycopene is likely to have a major role as an antioxidant in the process of spermatogenesis (28). Also, presence of adequate amounts of lycopene in cell membranes prevents oxidative damage of spermatozoa (36). Moreover, oral supplementation of lycopene increases its concentration in seminal plasma which will decrease oxidative stress and protect against ROS in seminal plasma (37).

Histopathological examination of testis and kidney tissues confirmed our biochemical findings. The observed degeneration and loss of spermatogenic series in the seminiferous tubules elucidate the decreased testosterone level. Similarly, the inflammatory cells infiltration in between the degenerated tubules at the renal cortex came in parallel with the increased serum IL-1 $\beta$ and TNF- $\alpha$. In contrast, co-administration of Bol + LC significantly ameliorated all pathological changes.

\section{CONCLUSION:}

This study suggested that boldenone misuse may produce detrimental effects on the testicular and renal structure and function which explain the increased incidence of infertility among athletes and bodybuilders injected with steroids. Regarding the obtained findings, we attributed the protective activity of lycopene on boldenone induced damaging effects to its powerful antioxidant activity. Therefore, we recommended that people should be careful in 
using steroids to improve their physical fitness. Moreover, antioxidant consumption, such as lycopene, by human beings and animals can lessen the negative effects of steroid exposure.

\section{Authors' contributions:}

All authors participated in the design of this work and performed equally. All authors read and approved the final manuscript.

\section{Acknowledgment:}

All authors would gratefully acknowledge all staff members in the Department of Forensic Medicine and Toxicology, Faculty of Veterinary Medicine, Benha University, Egypt for their technical support in the implementation of this study.

\section{REFERENCES:}

1. Tousson E, El-Moghazy M, Massoud A, Akel A. Histopathological and immuno histochemical changes in the testes of rabbits after injection with the growth promoter boldenone. Reprod Sci. 2012; 19(3):253-259.

2. Oda SS, El-Ashmawy IM. Adverse effects of the anabolic steroid, boldenone undecylenate, on reproductive functions of male rabbits. Int J Exp Pathol. 2012;93(3) :172-178.

3. Tousson E, El-Moghazy $M$, Massoud A, ElAtrash E, Sweef O, Akel A. Physiological and biochemical changes after boldenone injection in adult rabbits. Toxicol Ind Health. 2013;32:1-6.

4. De Brabander HF, Poelmans $S$, Schilt $R$, Stephany RW, Le Bizec B, Draisci $R$, et al. Presence and metabolism of the anabolic steroid boldenone in various animal species: a review. Food Addit Contam. 2004;21(6): 515-525.

5. Clark AS, Henderson LP. Behavioral and physiological responses to anabolicandrogenic steroids. Neurosci Biobehav Rev. 2003;27(5):413-436.
6. Dohle GR, Smit M, Weber RF. Androgens and male fertility. World J Urol. 2003;21(5):341345.

7. Parssinen M, Seppala T. Steroid use and long-term health risks in former athletes. Sports Med. 2002;32(2):83-94.

8. Alm-Eldeen A, Tousson E. Deterioration of glomerular endothelial surface layer and the alteration in the renal function after a growth promoter boldenone injection in rabbits. Hum Exp Toxicol. 2012;31(5):465472.

9. Woodall $A A$, Lee $S W$, Weesie RJ, Jackson MJ, Britton G. Oxidation of carotenoids by free radicals: relationship between structure and reactivity. Biochim Biophys Acta. 1997;1336 (1):33-42.

10. Rao AV, Agarwal S. Role of lycopene as antioxidant carotenoid in the prevention of chronic diseases: A review. Nutr Res. 1999;19(2):305-323.

11. Stahl W, Schwarz W, Sundquist AR, Sies $H$. cis-trans isomers of lycopene and betacarotene in human serum and tissues. Arch Biochem Biophys. 1992;294(1):173-177.

12. Ozten-Kandaş N, Bosland MC. Chemoprevention of prostate cancer: Natural compounds, antiandrogens, and antioxidants - In vivo evidence. J Carcinog. 2011;10:27-.

13. Sonmez M, Turk G, Ceribasi AO, Sakin F, Atessahin A. Attenuating effect of lycopene and ellagic acid on 2,3,7,8-tetrachlorodibenzo-p-dioxin-induced spermiotoxicity and testicular apoptosis. Drug Chem. Toxicol. 2011;34(4):347-356.

14. Dahan K, Fennal M, Kumar NB. Lycopene in the prevention of prostate cancer. SIO. 2008;6(1):29-36.

15. Gabr F, Abo El-Maaty A, Amal M, Aotifa AM. Effects of growth promoter boldenone undecylenate on weaned male lambs. Nat Sci. 2009; 7:61-69.

16. Mesbah L, Boulkour S, Narimane S, Fillastre JP. Protective affect of flavonoides against the toxity of vinblastine, cyclophosphamide and paracetamol by inhibition of lipid- 
peroxydation and increase of liver glutathion. Haematol. 2004;7(1):59-67.

17. Benzie IF, Strain JJ. The ferric reducing ability of plasma (FRAP) as a measure of "antioxidant power": the FRAP assay. Anal Biochem. 1996;239(1):70-76.

18. Aebi H. Catalase in vitro. Methods Enzymol. 1984;105:121-6.

19. Perandones CE, Illera VA, Peckham D, Stunz $\mathrm{LL}$, Ashman RF. Regulation of apoptosis in vitro in mature murine spleen $T$ cells. J. Immunol. 1993;151(7):3521-3529.

20. Livak KJ, Schmittgen TD. Analysis of relative gene expression data using real-time quantitative PCR and the 2(-Delta Delta $C(T)$ ) Method. Methods. 2001;25(4):402-408.

21. Ahmed NFN. Effect of Boldenone undecylenate on haematological and biochemical parameters in veal calves. Glob Vet. 2014;13:1092-1096.

22. El-Moghazy $M$, Tousson $E$, Sakran $M$. Changes in the hepatic and renal structure and function after a growth promoter boldenone injection in rabbits. Anim Biol. 2012;62:171-180.

23. Sinha Hikim AP, Swerdloff RS. Hormonal and genetic control of germ cell apoptosis in the testis. Rev Reprod. 1999;4(1):38-47.

24. Lopez-Castejon G, Brough D. Understanding the mechanism of IL-1beta secretion. Cytokine Growth Factor Rev. 2011;22(4): 189-195.

25. Walsh LJ, Trinchieri G, Waldorf HA, Whitaker D, Murphy GF. Human dermal mast cells contain and release tumor necrosis factor alpha, which induces endothelial leukocyte adhesion molecule 1. Proc Natl Acad Sci U S A. 1991;88(10):4220-4224.

26. Nair S, Rajamohan T. The Role of Coconut Water on Nicotine-Induced Reproductive Dysfunction in Experimental Male Rat Model. Food Nutr Sci. 2014;5:1121-1130.

27. Turk G, Atessahin A, Sonmez M, Yuce A, Ceribasi AO. Lycopene protects against cyclosporine A-induced testicular toxicity in rats. Theriogenology. 2007;67(4):778-785.

28. Zini A, San Gabriel M, Libman J. Lycopene supplementation in vitro can protect human sperm deoxyribonucleic acid from oxidative damage. Fertil Steril. 2010;94(3):1033-1036.

29. Devaraj S, Mathur S, Basu A, Aung HH, Vasu VT, Meyers S, et al. A dose-response study on the effects of purified lycopene supplementation on biomarkers of oxidative stress. J Am Coll Nutr. 2008;27(2):267-273.

30. Stahl W, Sies H. Antioxidant activity of carotenoids. Mol Aspects Med. 2003;24 (6):345-351.

31. Williams AA, Selvaraj J, Srinivasan C, Sathish $S$, Rajesh P, Balaji V, et al. Protective role of lycopene against Aroclor 1254-induced changes on GLUT4 in the skeletal muscles of adult male rat. Drug Chem Toxicol. 2013;36(3):320-328

32. Salem NA, Salem EA. Hepatorenal and Testicular Protective Effects of Lycopene against Cadmium Induced Toxicity in Male Rats. . J Nephrol Ther. 2016;6(5):1-7.

33. Atessahin A, Karahan I, Turk G, Gur S, Yilmaz $S$, Ceribasi AO. Protective role of lycopene on cisplatin-induced changes in sperm characteristics, testicular damage and oxidative stress in rats. Reprod Toxicol. 2006;21(1):42-47.

34. Gupta NP, Kumar R. Lycopene therapy in idiopathic male infertility--a preliminary report. Int Urol Nephrol. 2002;34(3):369 372.

35. Palan $\mathrm{P}, \mathrm{Naz}$ R. Changes in various antioxidant levels in human seminal plasma related to immunoinfertility. Arch Androl. 1996;36(2):139-143.

36. Erdman JW, Jr., Bierer TL, Gugger ET. Absorption and transport of carotenoids. Ann N Y Acad Sci. 1993;691:76-85.

37. Goyal A, Chopra M, Lwaleed BA, Birch B, Cooper AJ. The effects of dietary lycopene supplementation on human seminal plasma. BJU Int. 2007;99(6):1456-1460. 